\title{
Addition of alkynes at bridging vinyliminium ligands in diiron complexes: unprecedented diene formation by enyne-like metathesis.
}

\author{
Luigi Busetto ${ }^{\mathrm{a}}$, Fabio Marchetti, ${ }^{\mathrm{b}}$ Stefano Zacchini, ${ }^{\mathrm{a}}$ Valerio Zanotti ${ }^{\mathrm{a}^{*}}$ \\ ${ }^{a}$ Dipartimento di Chimica Fisica e Inorganica, Università di Bologna, Viale Risorgimento 4, \\ I-40136 Bologna, Italy \\ ${ }^{b}$ Dipartimento di Chimica e Chimica Industriale, Università di Pisa, Via Risorgimento 35, I- \\ 56126 Pisa, Italy.
}

\begin{abstract}
The zwitterionic bridging vinyliminium complex $\left[\mathrm{Fe}_{2}\left\{\mu-\eta^{1}: \eta^{3}-\mathrm{C}(\mathrm{Tol})=\mathrm{C}\left(\mathrm{CS}_{2}\right) \mathrm{C}=\mathrm{N}(\mathrm{Me})_{2}\right\}(\mu-\right.$ $\left.\mathrm{CO})(\mathrm{CO})(\mathrm{Cp})_{2}\right]$ (5a) undergoes the addition of two equivalents of $\mathrm{MeO}_{2} \mathrm{C}-\mathrm{C} \equiv \mathrm{C}-\mathrm{CO}_{2} \mathrm{Me}$ affording the bridging bis-alkylidene complex $\left[\mathrm{Fe}_{2}\left\{\mu-\eta^{1}: \eta^{3}-\right.\right.$ $\left.\left.\mathrm{C}(\mathrm{Me}) \mathrm{C}\left\{\mathrm{C}\left(\mathrm{CO}_{2} \mathrm{Me}\right) \mathrm{C}\left(\mathrm{CO}_{2} \mathrm{Me}\right) \mathrm{CSC}\left(\mathrm{CO}_{2} \mathrm{Me}\right) \mathrm{C}\left(\mathrm{CO}_{2} \mathrm{Me}\right) \mathrm{S}\right\} \mathrm{CNMe}_{2}\right\}(\mu-\mathrm{CO})(\mathrm{CO})(\mathrm{Cp})_{2}\right]$

One alkyne unit inserts into a $\mathrm{C}-\mathrm{CS}_{2}$ bond of the bridging ligand, with consequent rearrangement that leads to the formation of a diene. The reaction shows analogies with the enyne metathesis. The second alkyne is incorporated into the bridging frame via cycloaddition at the thiocarboxylate function, affording a 1,3-dithiolene. The complexes $\left[\mathrm{Fe}_{2}\left\{\mu-\eta^{1}: \eta^{3}-\mathrm{C}\left(\mathrm{R}^{\prime}\right)=\mathrm{C}\left(\mathrm{CS}_{2}\right) \mathrm{C}=\mathrm{N}(\mathrm{Me})(\mathrm{R})\right\}(\mu-\mathrm{CO})(\mathrm{CO})(\mathrm{Cp})_{2}\right]\left(\mathrm{R}=\mathrm{Xyl}, \mathrm{R}{ }^{\prime}=\mathrm{Tol}, \mathbf{5 b} ; \mathrm{R}=\mathrm{p}-\right.$ $\mathrm{C}_{6} \mathrm{H}_{4} \mathrm{OMe}, \mathrm{R}^{\prime}=\mathrm{Me}, \mathbf{5} \mathbf{c} ; \quad \mathrm{Xyl}=2,6-\mathrm{Me}_{2} \mathrm{C}_{6} \mathrm{H}_{3}$ ), treated with $\mathrm{MeO}_{2} \mathrm{C}-\mathrm{C} \equiv \mathrm{C}-\mathrm{CO}_{2} \mathrm{Me}$ and then with $\mathrm{HBF}_{4}$, undergo the cycloaddition of the alkyne with the dithiocarboxylate group and protonation of the dithiocarboxylate carbon, affording the complexes $\left[\mathrm{Fe}_{2}\left\{\mu-\eta^{1}: \eta^{3}-\right.\right.$ $\left.\left.\mathrm{C}\left(\mathrm{R}^{\prime}\right)=\mathrm{C}\left\{\mathrm{C}(\mathrm{H}) \mathrm{SC}\left(\mathrm{CO}_{2} \mathrm{Me}\right) \mathrm{C}\left(\mathrm{CO}_{2} \mathrm{Me}\right) \mathrm{S}\right\} \mathrm{C}=\mathrm{N}(\mathrm{Me})(\mathrm{R})\right\}(\mu-\mathrm{CO})(\mathrm{CO})(\mathrm{Cp})_{2}\right]\left[\mathrm{BF}_{4}\right]\left(\mathrm{R}=\mathrm{Xyl}, \mathrm{R}^{\prime}\right.$ $=$ Tol, 7a; $\left.\mathrm{R}=\mathrm{p}-\mathrm{C}_{6} \mathrm{H}_{4} \mathrm{OMe}, \mathrm{R}^{\prime}=\mathrm{Me}, \mathbf{7 b}\right)$, respectively.
\end{abstract}

The X-ray molecular structure of $\mathbf{6}$ has been determined.

Keywords: vinyliminium, diiron complexes, C-C bond formation, alkyne insertion, enyne metathesis, cycloaddition.

*Corresponding author. Tel.: +39 0512093695. 
E-mail address: valerio.zanotti@unibo.it (V.Zanotti)

${ }^{1}$ Fabio Marchetti, born in 1974 (fabmar@dcci.unipi.it). 


\section{Introduction}

Synthetic strategies based on transition-metal mediated assembly of simple molecular units are assuming a fundamental role for the construction of molecular architectures. In particular, metal mediated cycloadditions involving alkynes are emerging as powerful synthetic tool in the formation of $\mathrm{C}-\mathrm{C}$ and $\mathrm{C}-$ heteroatom bonds. Examples are numerous and include the Copper-Catalyzed Azide-Alkyne Cycloaddition (CuAAC) [1], which well illustrates the synthetic concepts developed by Sharpless for a rapid and "near perfect" assembly of molecules [1c] and provides a wealth of applications [2]. Other relevant examples are given by cycloaddition of vinylalkylidene ligands $(\alpha, \beta$-unsaturated carbenes) with alkynes, which have generated a number of synthetic protocols for the construction of cyclic molecules and heterocycles [4], including the classic Dotz benzannulation [5]. Our interest in this field has concerned the assembly of alkynes with bridging ligands in diiron complexes; thus we have shown that bridging vinylalkylidenes, as well as related $\mu$ vinyliminium ligands, can be involved in cycloaddition reactions [6]. An example, shown in Scheme 1, illustrates the [3+2] cycloaddition of the $\mu$-vinylalkylidene complex 1 with $\mathrm{PhC} \equiv \mathrm{CPh}$, leading to the formation of a cyclopentadienyl ligand and affording a ferrocene product [6a]. A peculiar aspect is that the cyclopentadienyl ligand contains several functionalities, which are those previously present on the parent $C_{3}$ and $C_{2}$ fragments. Therefore, the reaction, which has a general character, provides access to polyfunctionalized ferrocene complexes that are otherwise difficult to synthesize [7]. It should also be noted that formation of ferrocene products implies the fragmentation of the parent dinuclear complex; in the example shown in Scheme 1 this formally corresponds to the loss of $\left[\mathrm{HFeCO}_{2} \mathrm{Cp}\right]$.

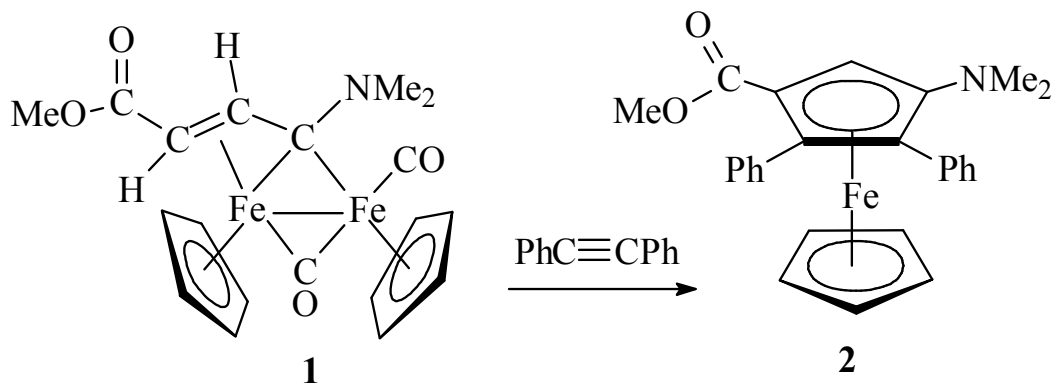

\section{Scheme 1}


Cycloadditions involving bridging ligands do not necessarily produce fragmentation of the diiron frame. We have shown that diiron complexes with zwitterionic bridging vinyliminium ligands can be involved in 1,3 dipolar cycloadditions with alkynes acting as dipolarophiles [8]. One example shown in Scheme 2. In this case, the presence of a negative charge on the $\mathrm{S}$ atom and of a positive charge on the iminium group sustains a 1,3 dipolar cycloaddition. Indeed, the reaction exhibits a more complex profile, in that different addition products have been obtained by varying the reaction conditions, and up to two alkyne units have been incorporated into the bridging ligand [8].
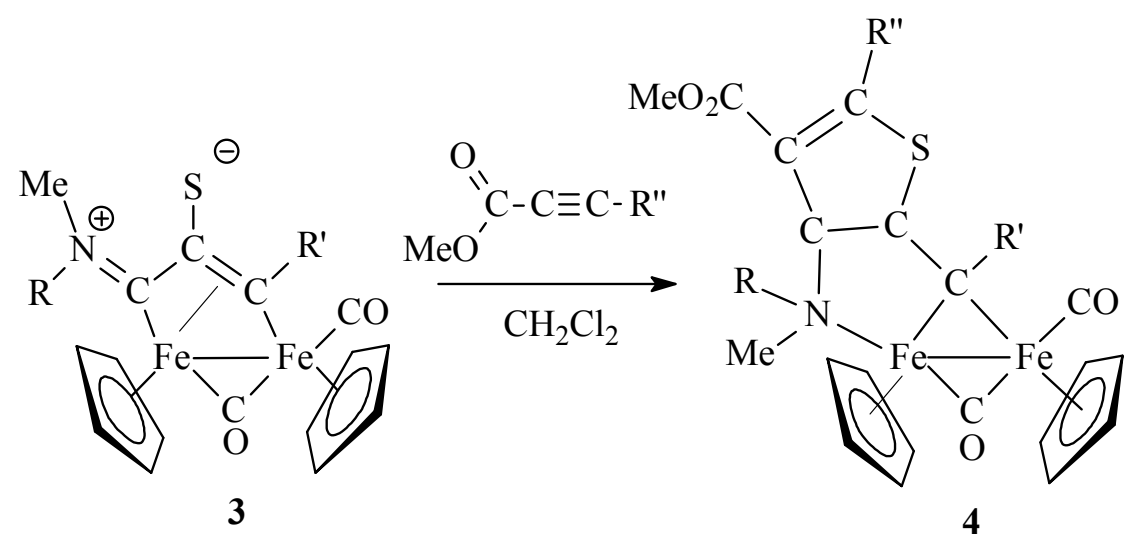

\section{Scheme 2}

In consideration of the versatile and unprecedented nature of these cycloaddition reactions, we decided to extend our investigations to the zwitterionic vinyliminium complexes 5 [9] (Chart 1). Compared to $\mathbf{3}$, compounds 5 display a dithiocarboxylate group in place of S. Therefore, the negative charge is more delocalized and distant from the iminium group. Complexes $\mathbf{5}$ have the potential to react with alkynes and are the subject of the investigation reported herein. The aim was to explore new routes for the assembly of alkynes with bridging fragments in diiron complexes. 


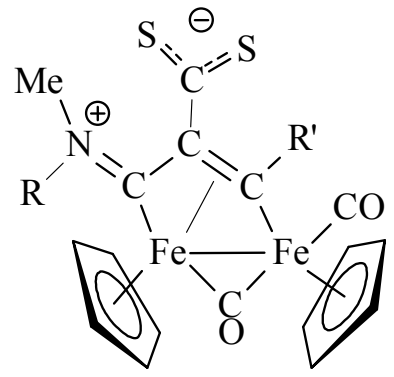

$\begin{array}{lll} & \mathbf{R} & \text { R' } \\ \mathbf{5 a} & \mathrm{Me} & \mathrm{Me} \\ \mathbf{5 b} & \mathrm{Xyl} & \mathrm{Tol} \\ \mathbf{5 c} & \mathrm{p}-\mathrm{C}_{6} \mathrm{H}_{4} \mathrm{OMe} & \mathrm{Me}\end{array}$

Chart 1 The bridging vinyliminium complexes investigated in this work.

\section{Results and discussion}

The zwitterionic vinyliminium complex 5a reacts with an excess of $\mathrm{MeO}_{2} \mathrm{C}-\mathrm{C} \equiv \mathrm{C}-\mathrm{CO}_{2} \mathrm{Me}$ affording the bis-alkylidene complex 6 in good yields (Scheme 3). Carbon atoms in the bridging chain, and $\mathrm{Fe}$ atoms have been numbered to make clearer the discussion presented hereafter.

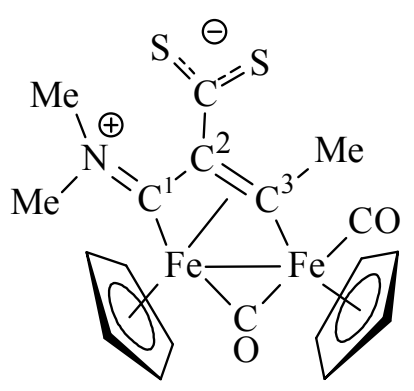

5a<smiles></smiles>

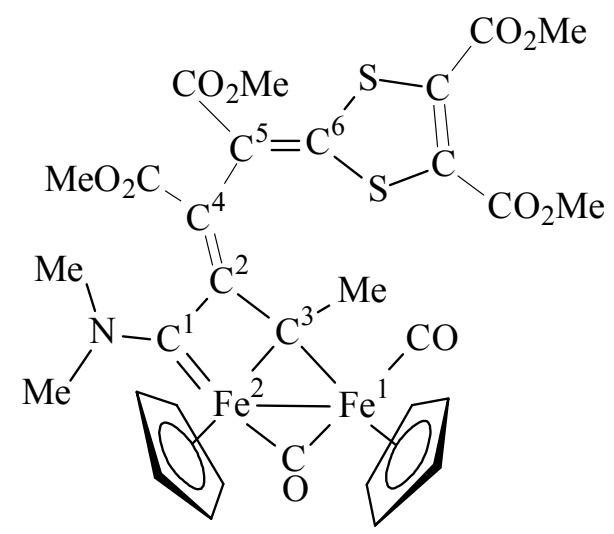

6

\section{Scheme 3.}


Complex 6 has been characterized by IR and NMR spectroscopy, elemental analysis and X-ray diffraction. The ORTEP molecular diagram is shown in Figure 1, whereas relevant bond lengths and angles are reported in Table 1.

The molecular structure of $\mathbf{6}$ is constituted by a $c i s-\mathrm{Fe}_{2}(\mu-\mathrm{CO})(\mathrm{CO})(\mathrm{Cp})_{2}$ unit to which is coordinated the bridging bis-alkylidene $\mu-\eta^{1}: \eta^{2}$ $\mathrm{C}(\mathrm{Me}) \mathrm{C}\left\{\mathrm{C}\left(\mathrm{CO}_{2} \mathrm{Me}\right) \mathrm{C}\left(\mathrm{CO}_{2} \mathrm{Me}\right) \mathrm{CSC}\left(\mathrm{CO}_{2} \mathrm{Me}\right) \mathrm{C}\left(\mathrm{CO}_{2} \mathrm{Me}\right) \mathrm{S}\right\} \mathrm{CNMe}_{2}$. The latter is closely related to the ketenimine-bis-alkylidene $\mu-\eta^{1}: \eta^{2}-\mathrm{C}(\mathrm{R}) \mathrm{C}(\mathrm{CNXyl}) \mathrm{CN}(\mathrm{Me})(\mathrm{Xyl})$ ligand $(\mathrm{R}=$ $\left.\mathrm{Me}, \mathrm{CO}_{2} \mathrm{Me}\right)$ found in $\left[\mathrm{Fe}_{2}\left\{\mu-\eta^{1}: \eta^{2}-\mathrm{C}(\mathrm{R}) \mathrm{C}(\mathrm{CNXyl}) \mathrm{CN}(\mathrm{Me})(\mathrm{Xyl})\right\}(\mu-\mathrm{CO})(\mathrm{CO})(\mathrm{Cp})_{2}\right]$ (I), [10], see Chart 2. Thus, the Fe(1)-C(3) [1.989(2) $\AA], \mathrm{Fe}(2)-\mathrm{C}(3)[2.006(2) \AA]$ and $\mathrm{Fe}(2)-\mathrm{C}(1)$ $\left[\begin{array}{ll}1.856(3) & \AA\end{array}\right]$ interactions are typical for a bridging alkylidene, $\mathrm{C}(3)$, and a terminal aminocarbene, C(1) [11]. In agreement with this, the $\mathrm{C}(1)-\mathrm{N}(1)$ [1.294(3) $\AA$ ] interaction displays a partial double bond character and N(1) shows an almost perfect $\mathrm{sp}^{2}$ hybridization [sum angles 359.6(3) ${ }^{\circ}$ ]. Interestingly, the $\mathrm{Fe}(2)-\mathrm{C}(2)$ distance $[2.320(2) \AA]$, even though longer than a normal $\sigma$-bond, is shorter than in $\left[\mathrm{Fe}_{2}\left\{\mu-\eta^{1}: \eta^{2}-\right.\right.$ $\left.\mathrm{C}(\mathrm{R}) \mathrm{C}(\mathrm{CNXyl}) \mathrm{CN}(\mathrm{Me})(\mathrm{Xyl})\}(\mu-\mathrm{CO})(\mathrm{CO})(\mathrm{Cp})_{2}\right](\mathbf{I})[2.52(2) \AA]$, [10] suggesting the presence of a weak interaction. From this point of view, 6 resembles the bis-alkylidene $\left[\mathrm{Fe}_{2}\{\mu-\right.$ $\left.\mathrm{C}(\mathrm{Me}) \mathrm{C}(\mathrm{O}) \mathrm{CN}(\mathrm{Me})(\mathrm{Xyl})\}(\mu-\mathrm{CO})(\mathrm{CO})(\mathrm{Cp})_{2}\right]$ (II) (Chart 2) [12] in which the analogous distance $[2.330(2) \AA]$ is intermediate between bonding and non-bonding. Therefore, even though the ligand in $\mathbf{6}$ can be mainly described as a bridging bis-alkylidene, it also possesses a minor character of vinyliminium.

The $\mathrm{C}(2)-\mathrm{C}(4)-\mathrm{C}(5)-\mathrm{C}(6)$ chain can be mainly described as an alternate diene $[\mathrm{C}(2)-$ $\mathrm{C}(4)$ 1.404(3) $\AA ; \quad \mathrm{C}(4)-\mathrm{C}(5)$ 1.477(3) $\AA$; $\mathrm{C}(5)-\mathrm{C}(6)$ 1.359(3) $\AA$ ] possessing a s-cis conformation. The terminal 1,3-dithiole ring is almost perfectly planar [deviation from the least square $\mathrm{C}(6), \mathrm{S}(1), \mathrm{S}(2), \mathrm{C}(14), \mathrm{C}(15)$ plane $0.0085 \AA$ ] with a localized double $\mathrm{C}=\mathrm{C}$ bond [C(14)-C(15) 1.339(4) Å]. 

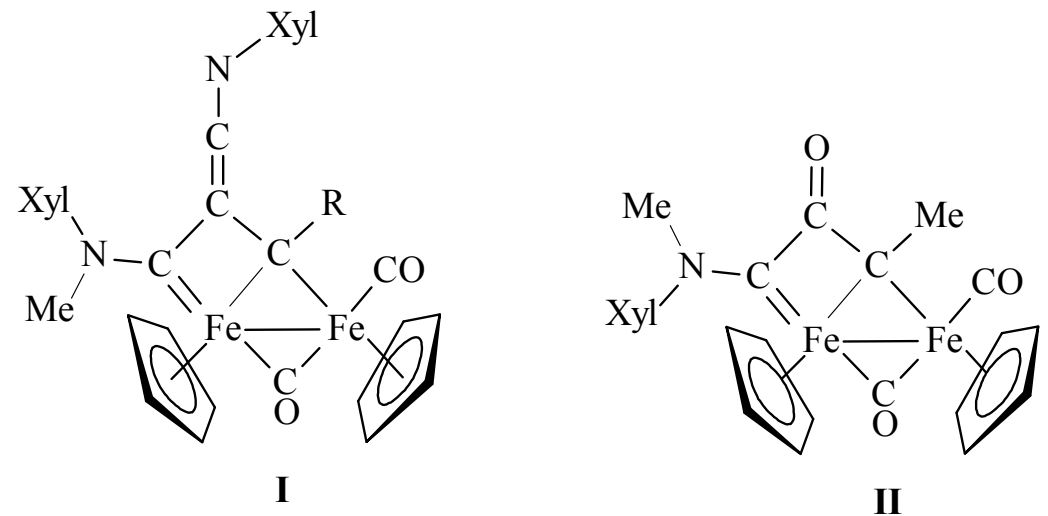

\section{Chart 2}

The IR spectrum of $\mathbf{6}$ (in $\mathrm{CH}_{2} \mathrm{Cl}_{2}$ solution) shows the usual pattern exhibited by diiron bis-alkylidene complexes, consisting of two absorptions due to terminal and bridging carbonyls (at 1948 and $1767 \mathrm{~cm}^{-1}$, respectively), and one band attributable to the $\mathrm{C}^{1}-\mathrm{N}$ interaction (at $1654 \mathrm{~cm}^{-1}$ ). Moreover, the carboxylate groups give rise to three mediumintensity absorptions, at $1751,1734,1720 \mathrm{~cm}^{-1}$. The most significant features in the ${ }^{13} \mathrm{C}$ NMR spectra of 6 include the resonances of the bridging carbons $C^{1}, C^{2}$ and $C^{3}$ (at $\delta 238.4,120.5$, and $183.8 \mathrm{ppm}$, respectively), which are consistent with the values normally observed in analogous bridging bis-alkylidene complexes previously reported $[10,13]$. The SCS carbon resonance is observed at $148.6 \mathrm{ppm}$, whereas the other two carbons within the 1,3-dithiole ring give rise to resonances at 160.4 and $160.3 \mathrm{ppm}$.

The formation of $\mathbf{6}$ shows several peculiar features that deserve a more detailed discussion. Two alkyne units are incorporated into the bridging frame, leading to the formation of two $\mathrm{C}=\mathrm{C}$ bonds (double bond) and two $\mathrm{C}-\mathrm{S}$ single bonds. Both transformations are unusual. In particular, one alkyne is formally inserted into a $\mathrm{C}-\mathrm{C}$ bond with consequent bond rearrangement leading to a butadiene. The reaction shows analogies with the enyne metathesis which occurs between alkene and alkynes producing conjugated dienes by $\pi$ bond reorganization, as shown in Scheme 4 [14]. Enyne metathesis, usually catalyzed by ruthenium carbenes [14b], has rapidly developed into a mild and effective method for the synthesis of conjugated cyclic and acyclic dienes, based on intramolecular rearrangements (ring closing enyne metathesis) [15] and intermolecular reactions (cross enyne metathesis) [16]. 


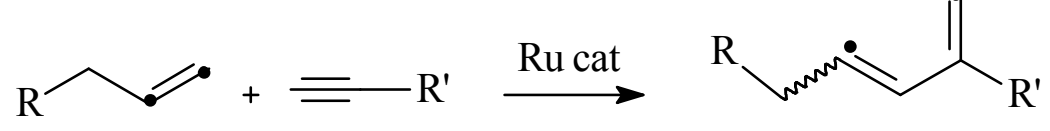

\section{Scheme 4}

The reaction leading to $\mathbf{6}$ is different from classic enyne metathesis, in that the $\mathrm{C}^{2}-\mathrm{CS}_{2}$ interaction involved in the bond rearrangement has predominantly a single bond character $\left(\mathrm{C}^{2}-\mathrm{CS}_{2}\right.$ bond distance in $\mathbf{5 b}$ is $1.522 \AA$ ) [9]. Thus, the observed formation of a butadienyl group is made possible by a change in the coordination mode of the bridging ligand, which remains connected to the iron atoms through the $\mathrm{C}^{1}$ and the $\mathrm{C}^{3}$ carbons, both assuming alkylidene character. Indeed $\mathrm{C}^{1}$ becomes a terminal alkylidene (Fischer type aminocarbene) and $\mathrm{C}^{3}$ a bridging alkylidene. The change in the coordination mode leaves $\mathrm{C}^{2}$ unbound to the metal centres and allows the formation of a $C=C$ double bond $\left(C^{2}=C^{4}\right.$ in Scheme 3). A corresponding rearrangement takes place at the thiocarboxylate carbon: incorporation into the five-membered cycle (1,3-dithiolene) allows the formation of a $\mathrm{C}=\mathrm{C}$ double bond $\left(\mathrm{C}^{5}=\mathrm{C}^{6}\right.$ in Scheme 3) and, thus, of a butadienyl group.

A second interesting point concerning the synthesis of $\mathbf{6}$ is the cycloaddition of the alkyne with the $\mathrm{CS}_{2}$ group. In general, this type of reaction is uncommon for dithiocarboxylates, as well as dithiocarbamates and xanthates. Examples are few and include the intramolecular cycloaddition observed in some S-propargyl xanthates, with formation of 1,3-dithiol-2-one species [17]. However, a more accurate survey of the literature revealed one example, reported by Regitz at al. in 1982, which exhibits several interesting analogies with our reaction, and that is shown in Scheme 5 [18]. 
<smiles>[R]N1CCN([R])C1C(S)S</smiles><smiles>[R]C#[R]CC[Y]</smiles><smiles>[R]#CCC</smiles>

\section{Scheme 5}

The imidazolium-dithiocarboxylates III were reported to undergo cycloaddition with acetylenes (notably acetylenedicarboxylates) to form IV. Interestingly, a second alkyne could be subsequently incorporated, affording $\mathbf{V}$ in a reaction that resembles the transformations occurring at the bridging frame of our diiron complexes. Also imidazoliumdiselenocarboxylates undergo cycloaddition with acetylenedicarboxylates in a reaction very similar to that shown in Scheme 5 [19]. To the best of our knowledge, these examples remained unique, in spite of recent renewed interest toward the chemistry of imidazoliumdithiocarboxylates [20].

The synthesis of $\mathbf{6}$ is most probably the result of a sequence of transformations; it is not clear whether alkynes are incorporated in subsequent steps or in a concerted process. The example shown in Scheme 5 suggests that the bridging ligand first undergoes cyclization at the dithiocarboxylate group, then the second alkyne inserts into the $\mathrm{C}-\mathrm{C}$ bond. A possible sequence is depicted in Scheme 6: the cycloaddition might produce the rearrangement of the bridging coordination generating the bis-alkylidene intermediate VI. If this description is realistic, the subsequent addition of alkyne would better fit with enyne metathesis, in that the $\mathrm{C}_{2}-\mathrm{CS}_{2}$ interaction displays a double bond character. 


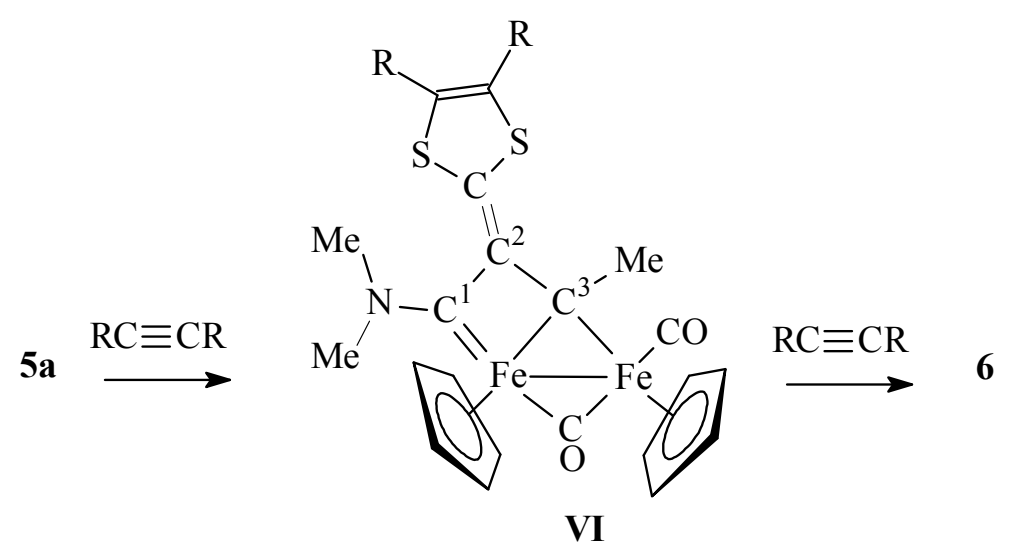

\section{Scheme 6}

In order to gain further evidences we treated $5 \mathbf{a}$ with an equimolar amount of $\mathrm{MeO}_{2} \mathrm{C}$ $\mathrm{C} \equiv \mathrm{C}-\mathrm{CO}_{2} \mathrm{Me}$, instead of using a large excess. The reaction still afforded 6, although in lower yield, and no other product generated by addition of one single molecule of alkyne was detected. Unfortunately, the observed double-addition seems to be limited to the acetylenedicarboxylate, in that other alkynes (e.g. $\mathrm{HC} \equiv \mathrm{CTol}$ or $\mathrm{HC} \equiv \mathrm{CSiMe}_{3}$ ) resulted unreactive under the same reaction conditions. We also found that changes in the substituents on the bridging ligand alter the reaction outcome. The complexes $\mathbf{5 b}$ and $\mathbf{5 c}$, which differ from 5a for the nature of one $\mathrm{N}$ substituent (aryl in place of methyl) and, in the case of $\mathbf{5} \mathbf{b}$, also for the nature of R' (see Chart 1), react with $\mathrm{MeO}_{2} \mathrm{C}-\mathrm{C} \equiv \mathrm{C}-\mathrm{CO}_{2} \mathrm{Me}$ in $\mathrm{CH}_{2} \mathrm{Cl}_{2}$ to form the complexes 7a and $\mathbf{7 b}$, respectively (Scheme 7). The most relevant aspect of these reactions is that only one equivalent of alkyne undergoes cycloaddition with the dithiocarboxylate group; a second alkyne unit is not incorporated into the bridging frame. Moreover, the transformation is accompanied by protonation of the thiocarboxylate carbon. The solvents used in the reaction, or in the subsequent workup, presumably act as proton source. Indeed, better yields (about $80 \%$ ) of $7 \mathbf{a}-\mathbf{b}$ have been achieved by treatment of the reaction mixture with $\mathrm{HBF}_{4}$ (see Experimental). Attempts to isolate the non-protonated intermediate (e.g. performing the reaction of $\mathbf{5 b}$ with $\mathrm{MeO}_{2} \mathrm{C}-\mathrm{C} \equiv \mathrm{C}-\mathrm{CO}_{2} \mathrm{Me}$ in THF) have been unsuccessful. 


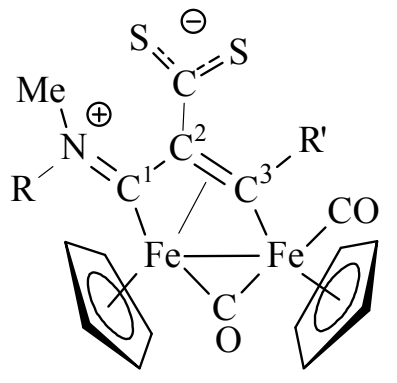

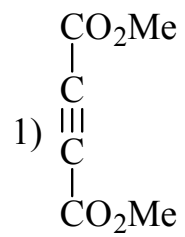

2) $\mathrm{HBF}_{4}$

$$
\underset{\mathrm{CH}_{2} \mathrm{Cl}_{2}}{\longrightarrow}
$$

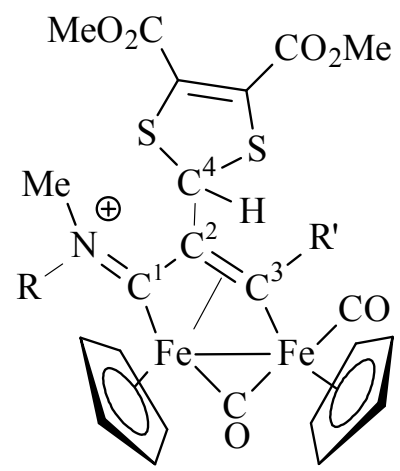

$\begin{array}{lll} & \mathbf{R} & \text { R' } \\ \text { 5b } & \text { Xyl } & \text { Tol } \\ \text { 5c } & \text { p- }{ }_{6} \mathrm{H}_{4} \mathrm{OMe} & \mathrm{Me}\end{array}$

$7 \mathbf{a}$

$7 \mathbf{b}$

\section{Scheme 7.}

Compounds $\mathbf{7 a - b}$ have been characterized by spectroscopic methods and elemental analysis.

The spectroscopic properties of $\mathbf{7 a}$ and $\mathbf{7 b}$ are consistent with those of their parent cationic vinyliminium complexes [9]. NMR data of $\mathbf{7 b}$ reveal the presence of minor amounts of a second isomeric form which is due to the possible orientations that the non-equivalent substituents ( $\mathrm{Me}$ and $\mathrm{p}-\mathrm{C}_{6} \mathrm{H}_{4} \mathrm{OMe}$ ) can assume with respect to the $\mathrm{C}=\mathrm{N}$ bond $(\mathrm{Z}$ and $\mathrm{E}$ isomers). NMR spectra and NOE investigations indicate that the $\mathrm{Z}$ configuration is predominant, which is fully consistent with the isomeric composition observed also in the precursor 5c [9]. Complexes 7a also display non-equivalent substituents a the $\mathrm{N}$ atom, but in this case one single isomer is observed, that is the same condition also found in the precursor 5b.

The formation of $\mathbf{7 a}$ and $\mathbf{7 b}$ further indicates that alkyne cycloaddition is likely the first step in the reaction sequence leading to 6 . Cycloaddition should generate an unsaturated and electron rich carbon (the thiocarboxylate carbon) which might react in two possible ways: a) promoting the addition of a second alkyne unit to form the diene derivative 6 ; $b$ ) undergoing protonation to yield the cationic products of type 7. Steric and electronic effects, associated with the nature of the groups that are present in the bridging ligand and on the alkyne molecule, might tune the reactivity of the intermediate species, and determine which path is most favourable. The precise nature of these effects are difficult to explain and predict, 
due to the limited number of data available so far. Investigations will be further extended and possible results will be matter of future reports.

\section{Conclusion}

Zwitterionic bridging vinyliminium ligands, bearing a dithiocarboxylate substituent, undergo addition of two alkyne units via $\mathrm{C}-\mathrm{C}$ and $\mathrm{C}-\mathrm{S}$ bond forming reaction that reveals unusual features. In particular, alkyne insertion into a $\mathrm{C}-\mathrm{C}$ bond results in the formation of a diene. The reaction shows analogies with the alkyne - alkene metathesis (enyne metathesis), except for the fact that the $\mathrm{C}-\mathrm{C}$ bond of the bridging frame involved in the assembly is a single bond with very little $\pi$ contribution. The cycloaddition involving the thiocarboxylate group and a second alkyne unit to form a 1,3-dithiolene is also unusual. The overall transformation leads to a considerable growth of the molecular architecture of the bridging frame, which is accompanied and made possible by a change in the bridging coordination mode. Unfortunately, the observed transformations do not display a general character, in that, even small variations of the substituents on both the bridging ligand and the alkyne reagent can be sufficient to give a different outcome. Nevertheless, our results add a further piece of evidence of the potential offered by diiron complexes in sustaining $\mathrm{C}-\mathrm{C}$ and $\mathrm{C}$-heteroatom bond formation through unprecedented transformations of bridging organic fragments. Finally, it should be remarked that reactions mediated by iron complexes contribute to the ongoing effort to the design of sustainable bond forming processes based on non toxic, readily available and inexpensive transition metals [21].

\section{Experimental details}

\subsection{General}

Reactions were routinely carried out under a nitrogen atmosphere, using standard Schlenk techniques. Solvents were distilled immediately before use under nitrogen from appropriate drying agents. Chromatography separations were carried out on deactivated alumina $(4 \% \mathrm{w} / \mathrm{w}$ water). Glassware was oven-dried before use. Infrared spectra were recorded at $298 \mathrm{~K}$ on a Perkin-Elmer Spectrum 2000 FT-IR spectrophotometer and elemental analyses were performed on a ThermoQuest Flash 1112 Series EA Instrument. NMR measurements were recorded at $298 \mathrm{~K}$ on Mercury Plus 400 instrument. The chemical shifts 
for ${ }^{1} \mathrm{H}$ and ${ }^{13} \mathrm{C}$ were referenced to internal TMS. The spectra were fully assigned via DEPT experiments and ${ }^{1} \mathrm{H},{ }^{13} \mathrm{C}$ correlation through gs-HSQC and gs-HMBC experiments. Resonances attributable to minor amounts of isomeric forms are italicized. All the reagents were commercial products (Aldrich) of the highest purity available and used as received. Complexes 5a-c were prepared as described in the literature [9].

4.2 Synthesis of $\left[\mathrm{Fe}_{2}\left\{\mu-\eta^{1}: \eta^{3}-\mathrm{C}^{3}(\mathrm{Me}) \mathrm{C}^{2}\left\{\mathrm{C}^{4}\left(\mathrm{CO}_{2} \mathrm{Me}\right) \mathrm{C}^{5}\left(\mathrm{CO}_{2} \mathrm{Me}\right) \mathrm{C}^{6} \mathrm{SC}\left(\mathrm{CO}_{2} \mathrm{Me}\right)\right.\right.\right.$ $\left.\left.\left.\mathrm{C}\left(\mathrm{CO}_{2} \mathrm{Me}\right) \mathrm{S}\right\} \mathrm{C}^{1} \mathrm{NMe}_{2}\right\}(\mu-\mathrm{CO})(\mathrm{CO})(\mathrm{Cp})_{2}\right](\boldsymbol{6})$.

A solution of $\mathbf{5 a}(90 \mathrm{mg}, 0.161 \mathrm{mmol})$, in $\mathrm{CH}_{2} \mathrm{Cl}_{2}(15 \mathrm{~mL})$ was treated with a two fold excess of $\mathrm{MeO}_{2} \mathrm{C}-\mathrm{C} \equiv \mathrm{C}-\mathrm{CO}_{2} \mathrm{Me}(0.35 \mathrm{mmol})$. The solution was stirred for $60 \mathrm{~min}$., then it was charged on an alumina column. Elution with neat THF afforded a dark green band, corresponding to $\mathbf{6}$. The product was obtained as a microcrystalline powder upon removal of the solvent. Yield: $97 \mathrm{mg}$; 85\%. Crystals of 6 suitable for X-ray analysis were obtained by layering a $\mathrm{CDCl}_{3}$ solution with petroleum ether, at $-20{ }^{\circ} \mathrm{C}$. Anal. Calcd. for $\mathrm{C}_{31} \mathrm{H}_{31} \mathrm{Fe}_{2} \mathrm{NO}_{10} \mathrm{~S}_{2}$ : C, 49.42; H, 4.15; N, 1.86. Found: C, 49.38; H, 4.21; N, 1.93. IR $\left(\mathrm{CH}_{2} \mathrm{Cl}_{2}\right): v(\mathrm{CO}) 1948$ (vs), 1767 (s), 1751 (m), 1734 (m), 1720 (m); v(CN) 1654 (w) cm ${ }^{-1} .{ }^{1} \mathrm{H}$ NMR (CDCl 3$)$ 4.83, 4.62 (s, $10 \mathrm{H}, \mathrm{Cp}) ; 3.89,3.81,3.80,3.49$ (s, $\left.12 \mathrm{H}, \mathrm{CO}_{2} \mathrm{Me}\right)$; 3.60, 2.82 (s, $\left.6 \mathrm{H}, \mathrm{NMe}\right) ; 3.18$ (s, $3 \mathrm{H}$, $\left.\mathrm{C}^{3} \mathrm{Me}\right) .{ }^{13} \mathrm{C}\left\{{ }^{1} \mathrm{H}\right\}$ NMR $\left(\mathrm{CDCl}_{3}\right) \delta 273.3(\mu-\mathrm{CO}) ; 238.4\left(\mathrm{C}^{1}\right) ; 213.6(\mathrm{CO}) ; 183.8\left(\mathrm{C}^{3}\right) ; 164.6$, 164.1, 163.6, $163.1\left(\mathrm{CO}_{2} \mathrm{Me}\right)$; 160.4, $160.3\left(\mathrm{SC}-\mathrm{CO}_{2} \mathrm{Me}\right) ; 148.6\left(\mathrm{C}^{6}\right) ; 135.1,131.4\left(\mathrm{C}^{4}\right.$ and $\left.\mathrm{C}^{5}\right) ; 120.5\left(\mathrm{C}^{2}\right) ; 88.2,87.5(\mathrm{Cp}) ; 53.1,53.0,51.9,50.7\left(\mathrm{CO}_{2} \mathrm{Me}\right) ; 45.1,42.5(\mathrm{NMe}) ; 41.7$ $\left(\mathrm{C}^{3} \mathrm{Me}\right)$.

4.3 Synthesis of $\left[\mathrm{Fe}_{2}\left\{\mu-\eta^{1}: \eta^{3}-C^{3}\left(R^{\prime}\right)=C^{2}\left\{\mathrm{C}(\mathrm{H}) \mathrm{SC}\left(\mathrm{CO}_{2} \mathrm{Me}\right) \mathrm{C}\left(\mathrm{CO}_{2} \mathrm{Me}\right) S\right\} C^{1}=N(\mathrm{Me})(\mathrm{R})\right\}(\mu-\right.$ CO)(CO) $\left.(C p)_{2}\right]\left[\mathrm{BF}_{4}\right] \quad\left(R=X y l, R^{\prime}=T o l, \quad 7 \boldsymbol{a} ; \quad R=p-C_{6} H_{4} O M e, R^{\prime}=M e, 7 \boldsymbol{b}\right)$. $\left(\mathrm{CO}_{2} \mathrm{Me}\right) \mathrm{C} \equiv \mathrm{C}\left(\mathrm{CO}_{2} \mathrm{Me}\right)(0.20 \mathrm{mmol})$ was added to

A solution of $\mathbf{5 b}(88 \mathrm{mg}, 0.138 \mathrm{mmol})$, in $\mathrm{CH}_{2} \mathrm{Cl}_{2}(15 \mathrm{~mL})$. The solution was stirred for 30 minutes, and then $\mathrm{HBF}_{4}(0.14 \mathrm{mmol})$ in solution of $\mathrm{Et}_{2} \mathrm{O}$ was added dropwise. The resulting mixture was stirred for additional 10 minutes. Removal of the volatile material under vacuum and chromatography of the residue on an alumina column, with $\mathrm{MeOH}$ as eluent, gave a brown band corresponding to 7a. The final product was obtained as a reddish-brown powder upon removal of the solvent under reduced pressure. Yield: $94 \mathrm{mg}, 79 \%$. Anal. Calcd. for 
$\mathrm{C}_{38} \mathrm{H}_{36} \mathrm{BF}_{4} \mathrm{Fe}_{2} \mathrm{NO}_{6} \mathrm{~S}_{2}: \mathrm{C}, 52.74 ; \mathrm{H}, 4.19 ; \mathrm{N}, 1.62$. Found: C, 51.98; H, 4.29; N, 1.65. IR $\left(\mathrm{CH}_{2} \mathrm{Cl}_{2}\right)$ : v(CO) 1991 (vs), 1832 (s), $1734(\mathrm{~m}) ; \mathrm{v}(\mathrm{CN}) 1607$ (m) cm ${ }^{-1} .{ }^{1} \mathrm{H}$ NMR $\left(\mathrm{CDCl}_{3}\right)$ 7.66-7.09 (m, $7 \mathrm{H}, \mathrm{Me}_{2} \mathrm{C}_{6} \mathrm{H}_{3}$ and $\left.\mathrm{C}_{6} \mathrm{H}_{4} \mathrm{Me}\right) ; 6.09$ (s, $\left.1 \mathrm{H}, \mathrm{CH}\right) ; 5.17,5.04$ (s, $\left.10 \mathrm{H}, \mathrm{Cp}\right) ; 3.76$ (s, $3 \mathrm{H}, \mathrm{NMe}) ; 3.74,3.70\left(\mathrm{~s}, 6 \mathrm{H}, \mathrm{CO}_{2} \mathrm{Me}\right) ; 2.76,1.93$ (s, $\left.6 \mathrm{H}, M_{2} \mathrm{C}_{6} \mathrm{H}_{3}\right): 2.43(\mathrm{~s}, 3 \mathrm{H}$, $\left.\mathrm{C}_{6} \mathrm{H}_{4} M e\right) .{ }^{13} \mathrm{C}\left\{{ }^{1} \mathrm{H}\right\} \mathrm{NMR}\left(\mathrm{CDCl}_{3}\right) \delta 248.8(\mu-\mathrm{CO}) ; 229.9\left(\mathrm{C}^{1}\right) ; 211.1(\mathrm{CO}) ; 206.6\left(\mathrm{C}^{3}\right) ; 160.5$ $\left(\mathrm{CO}_{2} \mathrm{Me}\right)$; 149.5, 141.4 (C $\left.\mathrm{C}_{\text {ipso-arom }}\right)$; 137.6-126.1 ( $\left.\mathrm{C}_{\text {arom }}\right)$; 126.7 (C-COOMe); 93.8, 88.3 (Cp); $67.8\left(\mathrm{C}^{2}\right) ; 54.4\left(\mathrm{C}^{4}\right) ; 53.7\left(\mathrm{CO}_{2} \mathrm{Me}\right) ; 52.7(\mathrm{NMe}) ; 21.2\left(\mathrm{MeC}_{6} \mathrm{H}_{4}\right) ; 19.4,19.1\left(\mathrm{Me}_{2} \mathrm{C}_{6} \mathrm{H}_{3}\right)$.

Compound $\mathbf{7 b}$ was prepared with the same procedure described for $7 \mathbf{a}$ by reacting $\mathbf{5 c}$ with $\mathrm{MeO}_{2} \mathrm{C}-\mathrm{C} \equiv \mathrm{C}-\mathrm{CO}_{2} \mathrm{Me}$ and then with $\mathrm{HBF}_{4}$.

7b (yield: 82\%). Anal. Calcd. for $\mathrm{C}_{31} \mathrm{H}_{30} \mathrm{BF}_{4} \mathrm{Fe}_{2} \mathrm{NO}_{7} \mathrm{~S}_{2}: \mathrm{C}, 47.06 ; \mathrm{H}, 3.82 ; \mathrm{N}, 1.77$. Found: $\mathrm{C}$, 47.21; H, 3.73; N, 1.84. IR $\left(\mathrm{CH}_{2} \mathrm{Cl}_{2}\right): \mathrm{v}(\mathrm{CO}) 1992$ (vs), 1824 (s), 1731 (m), v(CN) 1631 (m) $\mathrm{cm}^{-1} .{ }^{1} \mathrm{H}$ NMR (acetone- $\left.\mathrm{d}_{6}\right)$ 7.59, $7.22\left(\mathrm{~d}, 2 \mathrm{H},{ }^{3} \mathrm{~J}_{\mathrm{HH}}=8.78 \mathrm{~Hz}, \mathrm{C}_{6} \mathrm{H}_{4}\right) ; 7.13(\mathrm{~s}, 1 \mathrm{H}, \mathrm{CH}) ; 5.57$, 5.43, 5.24, 4.98 (s, $10 \mathrm{H}, \mathrm{Cp})$; 3.93, 3.91 (s, $\left.3 \mathrm{H}, \mathrm{C}^{3} \mathrm{Me}\right)$; 3.75, 3.74, 3.72, 3.70, 3.68 (s, $12 \mathrm{H}$, $\mathrm{NMe}, \mathrm{OMe}$ and $\mathrm{CO}_{2} \mathrm{Me}$ ). $Z / E$ ratio 8:1. ${ }^{13} \mathrm{C}\left\{{ }^{1} \mathrm{H}\right\}$ NMR (acetone-d $\left.\mathrm{d}_{6}\right) \delta 251.3(\mu-\mathrm{CO}) ; 226.6$ $\left(\mathrm{C}^{1}\right) ; 211.5210 .4(\mathrm{CO}) ; 202.2\left(\mathrm{C}^{3}\right) ; 160.9,160.8\left(\mathrm{CO}_{2} \mathrm{Me}\right) ; 160.2,135.6\left(\mathrm{C}_{i p s o \text {-arom }}\right) ; 130.8$, 129.4, 126.7 ( $\left.\mathrm{C}_{\text {arom }}\right)$; 122.1, $114.6\left(\mathrm{C}\right.$-COOMe); 92.6, 92.2, 88.9, 88.6 (Cp); $69.6\left(\mathrm{C}^{2}\right) ; 55.5$, $55.2\left(\mathrm{OMe}\right.$ and $\left.\mathrm{C}^{4}\right) ; 54.1,53.3,52.9\left(\mathrm{NMe}\right.$ and $\left.\mathrm{CO}_{2} \mathrm{Me}\right) ; 36.4\left(\mathrm{C}^{3} \mathrm{Me}\right)$.

\subsection{X-ray Crystallography for 6.}

Crystal data and collection details for $\mathbf{6}$ are reported in Table 2. The diffraction experiments were carried out on a Bruker Apex II diffractometer equipped with a CCD detector using Mo$\mathrm{K} \alpha$ radiation. Data were corrected for Lorentz polarization and absorption effects (empirical absorption correction SADABS)[22]. Structures were solved by direct methods and refined by full-matrix least-squares based on all data using $F^{2}$ [23]. All non-hydrogen atoms were refined with anisotropic displacement parameters, unless otherwise stated. $\mathrm{H}$-atoms were placed in calculated positions. H-atom were treated isotropically using the 1.2 fold $U_{\text {iso }}$ value of the parent atom except methyl protons, which were assigned the 1.5 fold $U_{\text {iso }}$ value of the parent C-atoms.

\section{Acknowledgement}


We thank the Ministero dell'Università e della Ricerca Scientifica e Tecnologica (M.I.U.R.)and the University of Bologna for financial support.

\section{Supplementary Material}

Crystallographic data for the structural analyses have been deposited with the Cambridge Crystallographic Data Centre, CCDC no. 821992 for 6. Copies of this information can be obtained free of charge from the Director, CCDC, 12 Union Road, Cambridge CB2 1EZ, UK (fax: +44-1233-336033; deposit@ccdc.cam.ac.uk or www.ccdc.cam.ac.uk). 


\section{References}

[1] (a) R. Huisgen, Pure Appl. Chem. 61 (1989) 613-628;

(b) R. Huisgen, G. Szeimies, L. Moebius, Chem. Ber. 100 (1967) 2494-2507;

(c) H. C. Kolb, M. G. Finn, K. B. Sharpless, Angew. Chem., Int. Ed. 40 (2001) 20042021.

[2] for recent reviews see: (a) M. Meldal, C. W. Tornøe, Chem. Rev. 108 (2008) 2952-3015.

(b) F. Amblard, J.-H. Cho, R. F. Schinazi, Chem Rev. 109 (2009) 4207-4220.

(c) J. E. Hein, V. V. Fokin, Chem. Soc. Rev. 39 (2010) 1302-1315;

(d) J. M. Holub, K, Kirshenbaum Chem. Soc. Rev. 39 (2010) 1325-1337.

[4] see for example: (a) K. H.Dötz, J. Stendel, Jr. Chem. Rev. 109 (2009) 3227-3274.

(b) A. De Meijere, H. Schirmer, M. Duetsch. Angew. Chem., Int. Ed. 39 (2000) 3964 4002.

(c) J. Barluenga, J. Santamaria, M. Tomas. Chem. Rev. 104 (2004) 2259-2283

(d) J. Barluenga. Pure Appl. Chem. 74 (2002) 1317-1325.

[5] (a) K. H. Dötz. Angew. Chem., Int. Ed. Engl. 14 (1975) 644-645;

(b) K. H. Dötz, P. Tomuschat. Chem. Soc. Rev. 28 (1999) 187-198.

[6] (a) L. Busetto, F. Marchetti, R. Mazzoni, M. Salmi, S. Zacchini, V. Zanotti, Organometallics 28 (2009) 3465-3472;

(b) L. Busetto, F. Marchetti, R. Mazzoni, M. Salmi, S. Zacchini, V. Zanotti, Chem. Commun. 46 (2010) 3327-3329;

(c) M. Salmi, L. Busetto, R. Mazzoni, S. Zacchini, V. Zanotti, Organometallics 30 (2011) 1175-1181.

[7] see for example: (a) C. Metallinos, J. Zaifman, L. Dodge, Org. Lett. 2008, 10, 35273530 ;

(b) A. H. Stoll, P. Mayer, P. Knochel, Organometallics 26 (2007) 6694-6697;

(c) Y. Wang, W. Weissensteiner, F. Spindler, V. B. Arion, K. Mereiter, Organometallics 26 (2007) 3530-3540.

[8] L. Busetto, F. Marchetti, F. Renili, S. Zacchini, V. Zanotti, Organometallics 29 (2010) $1797-1805$.

[9] F. Marchetti, S. Zacchini, M. Salmi, L. Busetto, V. Zanotti, Eur. J. Inorg, Chem. 29 (2011) 1260-1268. 
[10] L. Busetto, F. Marchetti, S. Zacchini, V. Zanotti, Organometallics 27 (2008) 50585066 .

[11] (a) F.H. Allen, O. Kennard, D.G. Watson, L. Brammer, A.G. Orpen, R. Taylor, J. Chem. Soc., Perkin Trans. (1987) S1-S19;

(b) A.G. Orpen, L. Brammer, F.H. Allen, O. Kennard, D.G. Watson, R. Taylor, J. Chem. Soc., Dalton Trans. (1989) S1-S83;

(c) L. Busetto, F. Marchetti, S. Zacchini, V. Zanotti, Organometallics 24 (2005) 22972306.

[12] L. Busetto, F. Marchetti, S. Zacchini, V. Zanotti, Organometallics 25 (2006) 48084816.

[13] (a) V.G. Albano, L. Busetto, F. Marchetti, M. Monari, S. Zacchini, V. Zanotti, Organometallics, 23 (2004) 3348-3354;

(b) V.G. Albano, L. Busetto, F. Marchetti, M. Monari, S. Zacchini, V. Zanotti, J. Organomet. Chem. 690 (2005) 837-846.

[14] (a) S.T. Diver, A.J. Giessert, Chem. Rev. 104 (2004) 1317-1382;

(b) S.T. Diver, Coord. Chem. Rev. 251 (2007) 671-701.

[15] (a) S.P. Nolan, H. Clavier, Chem. Soc. Rev. 39 (2010) 3305-3316;

(b) H. Villar, M, Frings, C. Bolm, Chem. Soc. Rev. 36 (2007) 55-66.

[16] (a) R. Stragies, M. Schuster, S. Blechert, Angew. Chem. Int. Ed. 36 (1997) 2518-2520;

(b) A. Kinoshita, N. Sakakibara, M. Mori, J. Am. Chem. Soc. 119 (1997) $12388-12389$.

[17] (a) S.Z. Zard, Angew. Chem. Int. Ed. Engl. 36 (1997) 612-685;

(b) J. Boivin, E.B. Henriet, C. Tailhan. S.Z. Zard, Tetrahedron Lett. 34 (1993) 27632766 ;

(c) J. Boivin. E.B. Henriet, S.Z. Zard, Tetrahedron Lett. 36 (1995) 5171-5174.

[18] W. Krasuski, D. Nikolaus, M. Regitz, Liebigs Ann. Chem. 8 (1982) 1451-1465.

[19] J. Nakayama, T. Kitahara, Y. Sugihara, A. Sakamoto, A. Ishii, J. Am. Chem. Soc. 122 (2000) 9120-9126.

[20] (a) L. Delaude, A. Demonceau, J. Wouters, Eur. J. Inorg. Chem. (2009) 1882-1891;

(b) S. Naeem, L. Delaude, A.J.P. White, J.D.E.T. Wilton-Ely, Inorg. Chem. 49 (2010) 1784-1793; 
(c) S. Naeem, A.L. Thompson, L. Delaude, J.D.E.T. Wilton-Ely, Chem. Eur. J. 16 (2010) 10971-10974.

[21] selected reviews include: (a) A. Correa, O. Garcia Mancheno, C. Bolm, Chem. Soc. Rev. 37 (2008) 1108-1117;

(b) C. Bolm, J. Legros, J. Le Paih, J. Zani Chem. Rev. 104 (2004) 6217-6254;

(c) R.H. Morris, Chem. Soc. Rev. 38 (2009) 2282-2291;

(d) B. Plietker (Ed.), Iron Catalysis in Organic Chemistry, Wiley-VCH, Weinheim, (2008);

(e) S. Enthaler, K. Junge, M. Beller, Angew. Chem. Int. Ed. 47 (2008) 3317-3321;

(f) C.-L. Sun, B.-J. Li, Z.-J. Shi, Chem. Rev. 111 (2011) 1293-1314.

[22] G.M. Sheldrick, SADABS, Program for Empirical Absorption Correction. University of Göttingen, Germany, (1996).

[23] G.M. Sheldrick, SHELX97-Program for the Refinement of Crystal Structure. University of Göttingen, Germany, (1997). 


\section{Figures}

Figure 1 Molecular structure of $\mathbf{6}$, with key atoms labelled (all $\mathrm{H}$ atoms have been omitted). Thermal ellipsoids are at the $30 \%$ probability level.

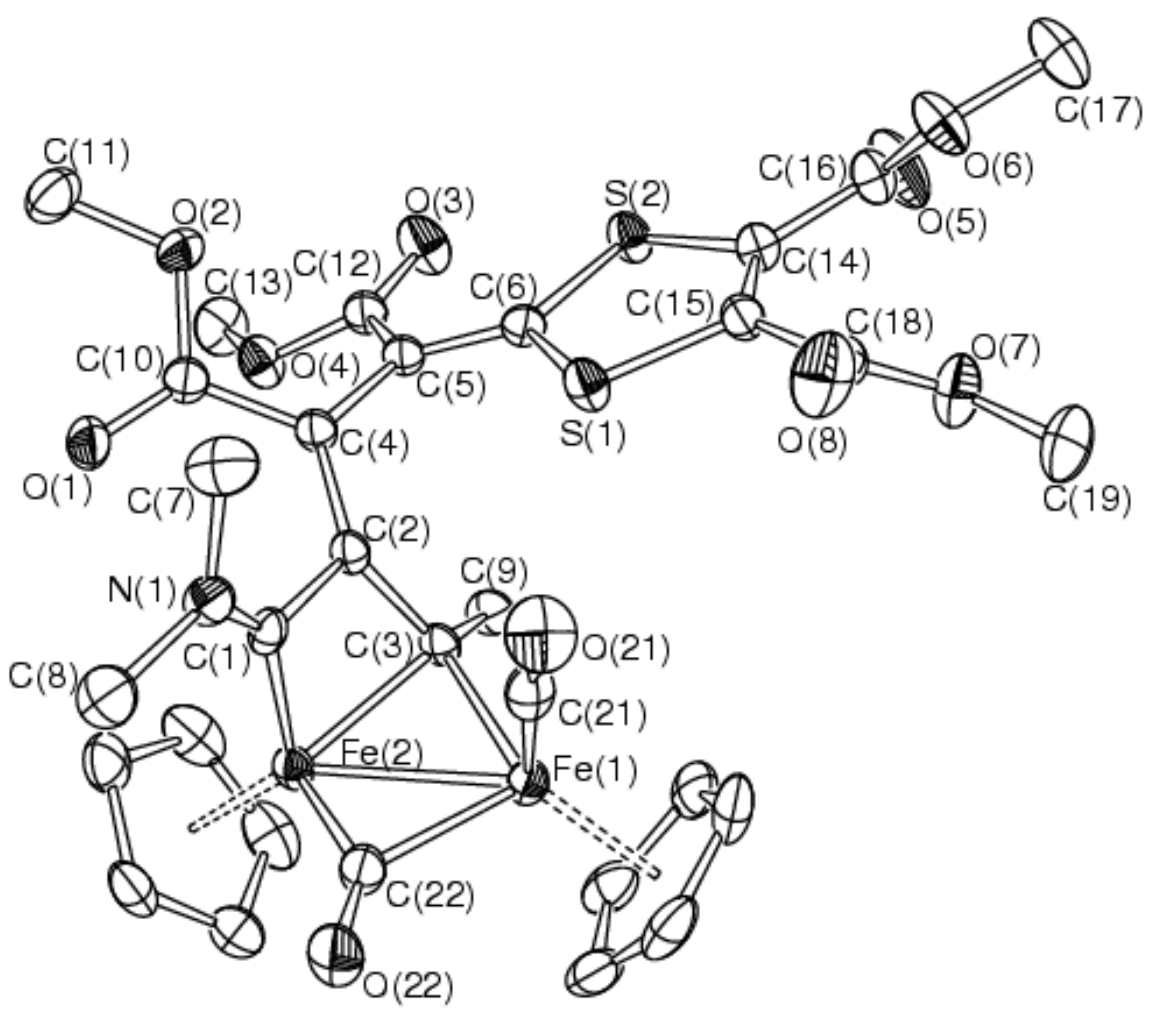


Table 1. Selected bond lengths $(\AA)$ and angles $\left(^{\circ}\right)$ for 6 .

\begin{tabular}{|c|c|c|c|}
\hline $\mathrm{Fe}(1)-\mathrm{Fe}(2)$ & $2.5312(5)$ & $\mathrm{C}(4)-\mathrm{C}(5)$ & $1.477(3)$ \\
\hline $\mathrm{Fe}(1)-\mathrm{C}(21)$ & $1.738(3)$ & $C(5)-C(12)$ & $1.470(3)$ \\
\hline $\mathrm{Fe}(1)-\mathrm{C}(22)$ & $1.967(3)$ & $\mathrm{C}(12)-\mathrm{O}(3)$ & $1.210(3)$ \\
\hline $\mathrm{Fe}(2)-\mathrm{C}(22)$ & $1.849(3)$ & $\mathrm{C}(12)-\mathrm{O}(4)$ & $1.332(3)$ \\
\hline $\mathrm{Fe}(1)-\mathrm{C}(3)$ & $1.989(2)$ & $C(5)-C(6)$ & $1.359(3)$ \\
\hline $\mathrm{Fe}(2)-\mathrm{C}(3)$ & $2.006(2)$ & $C(6)-S(1)$ & $1.751(2)$ \\
\hline $\mathrm{Fe}(2)-\mathrm{C}(2)$ & $2.320(2)$ & $C(6)-S(2)$ & $1.760(2)$ \\
\hline $\mathrm{Fe}(2)-\mathrm{C}(1)$ & $1.856(3)$ & $\mathrm{S}(2)-\mathrm{C}(14)$ & $1.754(3)$ \\
\hline $\mathrm{C}(21)-\mathrm{O}(21)$ & $1.156(3)$ & $\mathrm{C}(14)-\mathrm{C}(15)$ & $1.339(4)$ \\
\hline $\mathrm{C}(22)-\mathrm{O}(22)$ & $1.187(3)$ & $\mathrm{C}(15)-\mathrm{S}(1)$ & $1.743(3)$ \\
\hline $\mathrm{C}(2)-\mathrm{C}(3)$ & $1.462(3)$ & $C(14)-C(16)$ & $1.481(4)$ \\
\hline $\mathrm{C}(1)-\mathrm{C}(2)$ & $1.459(3)$ & $\mathrm{C}(16)-\mathrm{O}(5)$ & $1.197(3)$ \\
\hline $\mathrm{C}(1)-\mathrm{N}(1)$ & $1.294(3)$ & $\mathrm{C}(16)-\mathrm{O}(6)$ & $1.310(3)$ \\
\hline $\mathrm{C}(2)-\mathrm{C}(4)$ & $1.404(3)$ & $\mathrm{C}(15)-\mathrm{C}(18)$ & $1.479(4)$ \\
\hline$C(4)-C(10)$ & $1.454(3)$ & $\mathrm{C}(18)-\mathrm{O}(7)$ & $1.313(3)$ \\
\hline $\mathrm{C}(10)-\mathrm{O}(1)$ & $1.215(3)$ & $\mathrm{C}(18)-\mathrm{O}(8)$ & $1.458(4)$ \\
\hline $\mathrm{C}(10)-\mathrm{O}(2)$ & $1.356(3)$ & $\mathrm{C}(3)-\mathrm{C}(9)$ & $1.524(3)$ \\
\hline $\mathrm{Fe}(1)-\mathrm{C}(3)-\mathrm{Fe}(2)$ & $78.63(8)$ & $\mathrm{C}(4)-\mathrm{C}(5)-\mathrm{C}(6)$ & $121.5(2)$ \\
\hline $\mathrm{Fe}(1)-\mathrm{C}(3)-\mathrm{C}(2)$ & $120.49(16)$ & $\mathrm{C}(4)-\mathrm{C}(5)-\mathrm{C}(12)$ & $121.3(2)$ \\
\hline $\mathrm{C}(3)-\mathrm{C}(2)-\mathrm{C}(1)$ & $104.22(19)$ & $C(12)-C(5)-C(6)$ & $117.2(2)$ \\
\hline $\mathrm{C}(2)-\mathrm{C}(1)-\mathrm{N}(1)$ & $130.0(2)$ & $C(5)-C(6)-S(1)$ & $119.53(18)$ \\
\hline $\mathrm{C}(1)-\mathrm{N}(1)-\mathrm{C}(7)$ & $124.4(2)$ & $C(5)-C(6)-S(2)$ & $126.20(19)$ \\
\hline $\mathrm{C}(1)-\mathrm{N}(1)-\mathrm{C}(8)$ & $120.3(2)$ & $\mathrm{S}(1)-\mathrm{C}(6)-\mathrm{S}(2)$ & $114.25(14)$ \\
\hline $\mathrm{C}(7)-\mathrm{N}(1)-\mathrm{C}(8)$ & $114.9(2)$ & $\mathrm{C}(6)-\mathrm{S}(2)-\mathrm{C}(14)$ & $95.11(12)$ \\
\hline $\mathrm{C}(2)-\mathrm{C}(4)-\mathrm{C}(10)$ & $120.2(2)$ & $\mathrm{C}(15)-\mathrm{C}(14)-\mathrm{S}(2)$ & $117.5(2)$ \\
\hline$C(2)-C(4)-C(5)$ & $122.6(2)$ & $\mathrm{C}(14)-\mathrm{C}(15)-\mathrm{S}(1)$ & $117.2(5)$ \\
\hline $\mathrm{C}(10)-\mathrm{C}(4)-\mathrm{C}(5)$ & $117.1(2)$ & $\mathrm{C}(15)-\mathrm{S}(1)-\mathrm{C}(6)$ & $95.81(12)$ \\
\hline
\end{tabular}




\section{Table 2}

Crystal data and experimental details for $\mathbf{6}$.

\section{Formula}

$F_{\mathrm{W}}$

$T, K$

$\lambda, \AA$

Crystal system

Space group

$$
\begin{aligned}
& a, \AA \\
& b, \AA \\
& c, \AA \\
& \alpha,{ }^{\circ} \\
& \beta,{ }^{\circ} \\
& \gamma,{ }^{\circ}
\end{aligned}
$$

Cell volume, $\AA^{3}$

$$
\text { Z }
$$

$$
\begin{gathered}
D_{\mathrm{c}}, \mathrm{g} \mathrm{cm}^{-3} \\
\mu, \mathrm{mm}^{-1} \\
\mathrm{~F}(000)
\end{gathered}
$$

Crystal size, $\mathrm{mm}$

$\theta$ limits, ${ }^{\circ}$

Reflections collected

Independent reflections

Data/restraints/parameters

Goodness on fit on $\mathrm{F}^{2}$

$$
\begin{aligned}
& \mathrm{R}_{1}[I>2 \sigma(I)) \\
& w \mathrm{R}_{2} \text { (all data) }
\end{aligned}
$$

$\mathrm{C}_{31} \mathrm{H}_{31} \mathrm{Fe}_{2} \mathrm{NO}_{10} \mathrm{~S}_{2}$

753.39

296(2)

0.71073

Monoclinic

$P 2_{1} / c$

9.9601(5)

$32.3569(17)$

10.1358(5)

90

92.2470(10)

90

3264.0(3)

4

1.533

1.074

1552

$0.18 \times 0.15 \times 0.12$

2.05-27.10

37147

$7196\left(R_{\text {int }}=0.0538\right)$

7196 / 0 / 422

1.003

0.0389

0.0998

$0.500 /-0.233$ 


\title{
Graphical abstract
}

\section{Addition of alkynes at bridging vinyliminium ligand in diiron complexes: unprecedented diene formation by enyne-like metathesis.}

\author{
Luigi Busetto ${ }^{\mathrm{a}}$, Fabio Marchetti, ${ }^{\mathrm{b}}$ Stefano Zacchini, ${ }^{\mathrm{a}}$ Valerio Zanotti ${ }^{{ }^{*}}$ \\ ${ }^{a}$ Dipartimento di Chimica Fisica e Inorganica, Università di Bologna, Viale Risorgimento 4, \\ I-40136 Bologna, Italy \\ ${ }^{b}$ Dipartimento di Chimica e Chimica Industriale, Università di Pisa, Via Risorgimento 35, I- \\ 56126 Pisa, Italy.
}

A zwitterionic vinyliminium ligand, bridging two iron centres, incorporates two alkyne units: one is inserted into a $\mathrm{C}-\mathrm{C}$ bond affording a diene, the second alkyne undergoes cycloaddition with the dithiocarboxylate group affording a 1,3-dithiolene.
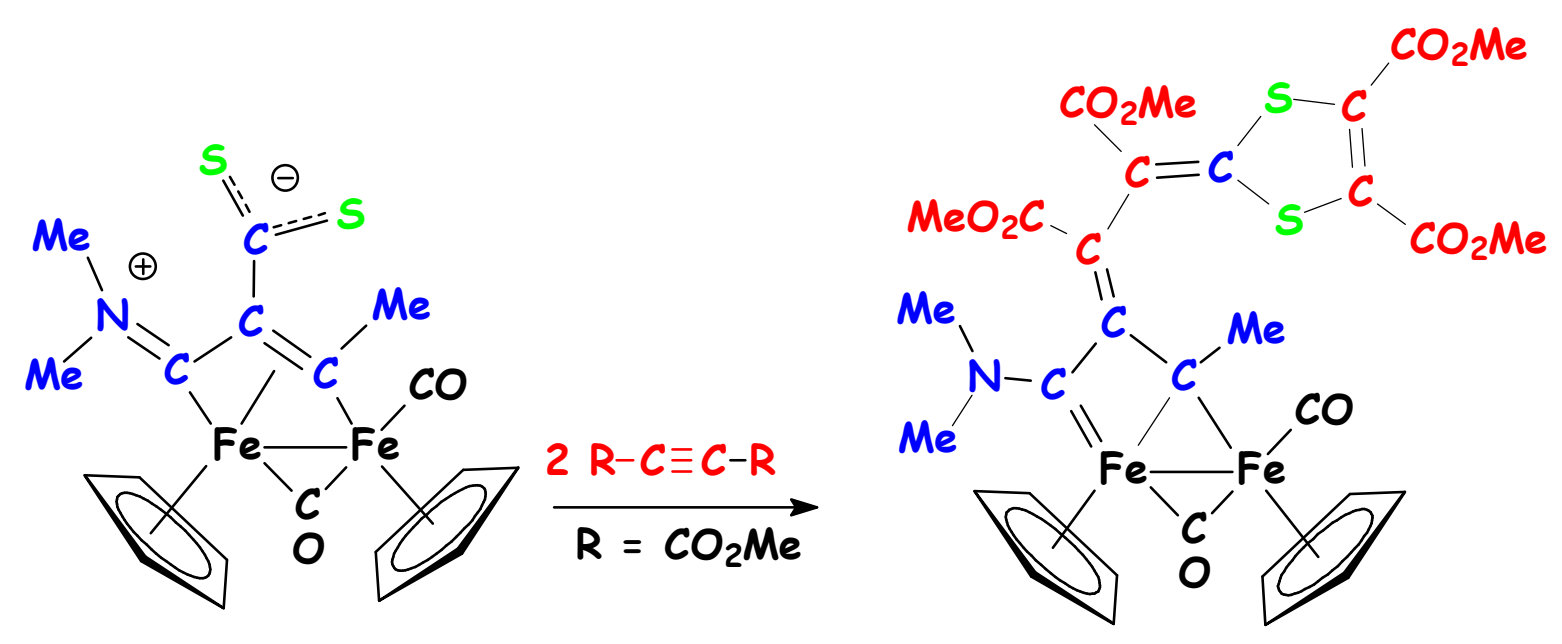